\title{
HLA molecules, bacteria and autoimmunity
}

\author{
A. EBRINGER* and C. WILSON \\ Division of Life Sciences, Infection and Immunity Group, King's College, 150 Stamford Street, London and \\ * Department of Rheumatology, UCL School of Medicine, Middlesex Hospital, London
}

\begin{abstract}
It has been well established that many diseases are linked to HLA antigens. Two of the most interesting HLA associations may provide some insight into the pathogenesis of rheumatic inflammatory conditions. In ankylosing spondylitis (AS), $96 \%$ of patients possess HLA-B27, whilst the frequency of this marker in the general population is $c$. $8 \%$. In rheumatoid arthritis (RA), $>90 \%$ of patients possess either HLA-DR1 or some subtypes of HLA-DR4, whilst the frequency of this marker in the general population is c. $35 \%$. The association between HLA-B27 and reactive arthritis $(\operatorname{Re} A)$ has also been well established. Furthermore, it has been shown that $\operatorname{ReA}$ is triggered by infection via the gastrointestinal tract due to Yersinia, Salmonella or Campylobacter spp. and in the genitourinary tract due to chlamydia. In a similar way, microbiological and immunological studies have revealed an association between Klebsiella pneumoniae in AS and Proteus mirabilis in RA. This article reviews the possible pathological implications of the associations between HLA-B27, K. pneumoniae and AS, as well as HLA-DR1/DR4, P. mirabilis and RA.
\end{abstract}

\section{Introduction}

Infectious agents have been postulated to play a role in the development of autoimmune diseases such as rheumatoid arthritis (RA), ankylosing spondylitis (AS), multiple sclerosis (MS) and insulin-dependent diabetes mellitus (IDDM). However, the underlying pathological mechanisms are at present unknown, although many theories have been proposed to explain these diseases.

\section{Rheumatic fever}

In rheumatic fever, antibodies to heart tissue have been shown to cross-react with Streptococcus pyogenes because of 'molecular mimicry' [1] and studies have identified antigenic structures that may be involved in cross-reactions with myocardial and brain components $[2,3]$. Two of the most characterised cross-reactive antigens associated with rheumatic fever are cardiac myosin and the $\mathrm{M}$ protein of $S$. pyogenes $[4,5]$. Affinity-purified anti-myosin antibodies from sera of patients with acute rheumatic fever have been shown to cross-react with a pentameric amino-acid sequence QKSKQ present in streptococcal M protein [5]. Studies

Received 2 Jan. 1999; revised version accepted 18 Oct. 1999.

Corresponding author: Professor A. Ebringer. have shown that murine anti-streptococcal monoclonal antibodies (MAbs) that were cross-reactive with streptococcal $\mathrm{M}$ protein and cardiac myosin were cytotoxic for heart and fibroblast cell lines [6]. Rheumatic fever could therefore be a model for a pathological mechanism that explains the development of other autoimmune diseases such as AS and RA.

\section{Ankylosing spondylitis}

Ankylosing spondylitis (AS) is a chronic inflammatory disorder that involves mainly the lumbar spine and sacroiliac joints, although it can also affect the peripheral joints and eye structures such as the uvea. The inflammation can lead to fibrosis and ossification, where bridging spurs of bone known as 'syndesmophytes' form, especially at the edges of the intervertebral discs. This form of ossification is primarily seen at the sacroiliac joints and lumbar spine from where it ascends. In extreme cases it can effectively solidify the whole of the vertebral column. In the advanced stages, fusion of the spine occurs, which often results in a characteristic stooped posture known as the 'Bechterew stoop'. The disease in severe cases can progress to form the classic 'bamboo spine'. It is well established that HLA-B27 is associated with AS in all racial groups examined $[7,8]$, but it must be noted that the majority of HLA-B27 carriers are free from disease. Class I major histocompatibility (MHC) 
molecules such as HLA-B27 are found on virtually all cells except mature erythrocytes and trophoblasts, whereas class II molecules like HLA-DR1/DR4 are present on B cells, monocytes and dendritic cells, where they are thought to play a role in antigen presentation to $\mathrm{T}$ cells. In addition, certain cells that do not normally express class II molecules can be induced to express them upon stimulation with interferongamma (IFN- $\gamma$ ) [9]. Two main theories have been proposed to explain the association of HLA-B27 with AS: the receptor theory and the molecular mimicry theory.

The receptor theory postulates that the T-cell receptor recognises foreign or self peptides, 8-20 amino acids in length, in association with class I or class II MHC molecules forming a trimolecular complex [10,11]. Thus, the T-cell response is restricted by HLA molecules. The HLA-DR1/DR4 binding groove could present a peptide of arthritogenic origin to $\mathrm{T}$ cells, which may be similar to a foreign peptide bound to an HLA molecule. The lack of evidence for a special pathogenic peptide that binds to HLA-B27 or to HLADR1/DR4 is a serious weakness of the 'receptor theory'.

The molecular mimicry theory suggests that disease is caused by antigenic components of micro-organisms which partially resemble or cross-react with HLA molecules. Once antibacterial antibodies have been produced as a result of infection, they will bind to HLA molecules on lymphocytes, fibroblasts and chondrocytes. Activation of the complement cascade will lead to inflammation and clinical symptoms of disease [12]. An alternative explanation for pathogenic, auto-reactive responses is through the presence of 'cryptic epitopes'. The principles of this theory are that each self-protein has a small number of well presented dominant epitopes which are involved in negative selection of $\mathrm{T}$ cells. Thus the majority of minor cryptic determinants do not induce tolerance and, therefore, there exists a large cohort of potentially self-reactive $T$ cells, which under certain circumstances may become activated [13]. The cryptic self theory is compatible with the molecular mimicry theory, as viruses or bacteria may provide the initial stimulus that leads to an increase in presentation of, and immune reactivity to, cryptic determinants. Structural similarity between dominant determinants in a foreign and self molecule have been documented [14]. Furthermore, self-reactive $\mathrm{T}$ and $\mathrm{B}$ cells have been primed following coimmunisation with both a self-reactive and a crossreactive foreign molecule [15]. Cryptic determinants may be present in the synovium and any similarity with antigenic sequences in an infecting organism could induce an auto-reactive response, which in turn could lead to inflammation and tissue damage. Reactive arthritis is known to occur in HLA-B27-positive individuals following infection with Salmonella, Shigella and Yersinia spp. Patients with acute $Y$. enterocolitica $\mathrm{O}: 3$ infection who develop arthritis tend to have a more persistent IgA antibody response to the infecting organism than those with uncomplicated infection [16]. Several groups have observed that synovial fluid mononuclear cells from patients with yersinia reactive arthritis show significantly higher proliferation than peripheral blood cells from the same patients in response to whole yersinia antigens $[17,18]$. Further analysis of synovial CD4 positive T-cell clones has shown that the principal responses are to antigens of the $19-\mathrm{kDa}$ urease subunit [19] and the 14-kDa L23 protein of the $50 \mathrm{~S}$ ribosomal subunit of Yersinia spp. [20]. Moreover, the urease protein has previously been shown to be arthritogenic in rats [21].

A prolonged IgA antibody response to both $S$. enteritidis and S. typhimurium has also been demonstrated in patients with reactive arthritis compared with those with uncomplicated infections [22]. Salmonella LPS, but not viable organisms, has been detected in synovial specimens from patients with salmonellainduced reactive arthritis [23]. Furthermore, synovial fluid $\mathrm{T}$ cells from reactive arthritis patients proliferate specifically when stimulated with salmonella antigens [18], whereas peripheral blood T-cell responses appear to be decreased [24]. Other studies have shown that LPS from Sh. flexneri can be detected in synovial samples from patients with reactive arthritis [25] and synovial fluid T-cell responses to shigella have also been observed in patients with reactive arthritis [26].

\section{Molecular mimicry between HLA-B27 and K. pneumoniae molecules}

The molecular mimicry theory was first proposed by our group in 1976, when it was shown that several gram-negative micro-organisms, such as $K$. pneumoniae, carry antigens that cross-react with HLA-B27 [12]. Allogeneic human HLA-B27 tissue typing antisera were found to bind preferentially to K. pneumoniae antigens compared with non-B27 typing sera $[27,28]$. Furthermore, mouse monoclonal anti-HLAB27 sera showed increased binding to klebsiella, shigella and yersinia antigens, but not to Enterobacter aerogenes and S. typhimurium antigens [29]. In a related study, an anti-Yersinia MAb reacted with all of 12 HLA-B27 lymphoblastoid cell lines, but with only four of 31 HLA-B27-negative ones. However, three of the four reactive HLA-B27-negative cell lines carried HLA-B7, an antigen that cross-reacts with HLA-B27 [30]. Other studies demonstrated that the anti-HLAB27 (M2) MAb bound specifically to a $70-\mathrm{kDa}$ component of $K$. pneumoniae, whereas no such reactivity was demonstrated with five other MAbs [31].

Molecular mimicry has also been demonstrated at the amino acid level. An amino-acid sequence homology has been identified between HLA-B27 and the $K$. pneumoniae nitrogenase reductase enzyme, in that the sequence QTDRED is common to both molecules [32]. 
In addition, rat antisera raised against 16-mer synthetic peptides of $K$. pneumoniae nitrogenase reductase which contained the similarity sequence, reacted with synovial biopsies obtained from HLA-B27-positive AS patients, but not with biopsies obtained from HLA-B27-negative RA patients [33]. Furthermore, AS patients have elevated levels of antibodies to $K$. pneumoniae nitrogenase reductase, especially during active phases of disease [34].

There is another klebsiella sequence, which crossreacts with part of the HLA-B27 molecule. Database analysis of published $K$. pneumoniae protein sequences showed that molecular mimicry is present between $K$. pneumoniae secretion protein (pul D) of the inducible, starch debranching enzyme pullulanase (DRDE) and HLA-B27 (DRED) [35]. Also, amino-acid homology has been described between the extracellular starchinduced enzymes pullulanase (pul A) and types I, III and IV collagens [35]. The molecular mimicry theory predicts that both antigen, i.e., the microbe, and antibodies against $K$. pneumoniae should be detectable in AS patients during active phases of the disease.

\section{Microbiological studies}

Early studies by our group of 63 AS patients showed that $K$. pneumoniae was isolated more frequently during active phases of the disease [36]. In the second sequential study, of 163 AS patients, it was shown that clinical relapse was preceded by the appearance of $K$. pneumoniae in faecal samples [37] and active inflammatory disease was associated with elevation in total serum IgA, suggesting that a microbial agent was acting across a mucosal surface, such as the gut [38]. Independently, other groups have found an association between the isolation of Klebsiella spp. and active disease in AS patients [39-41]. These studies on AS patients in several centres suggest that $K$. pneumoniae is involved in producing pathological changes during active phases of the disease. To explain the pathology of the disease, antibodies produced against crossreactive antigens and also against immunocompetent cells must be shown to produce autoimmune cellular and tissue damage.

\section{Immunological studies}

It is well established that total serum IgA is elevated in AS patients [42] and that it is usually associated with inflammatory phases of disease activity [38-43]. Elevation in total serum $\operatorname{IgA}$ indicates antigenic stimulation across a mucosal surface, such as the gastrointestinal or respiratory tracts. Plasma cells in the gut mucosa are the main source of serum IgA [44], therefore, gram-negative bowel flora could be responsible for these immunoglobulin elevations [45].

Early studies by our group reported that mean IgA antibody levels against freeze-dried, reconstituted culture supernate of $K$. pneumoniae were significantly higher in 43 active AS patients than in 39 inactive AS patients, 57 healthy control subjects, 13 patients with psoriatic arthritis and 38 rheumatoid arthritis (RA) patients. However, there were no significant elevations of antibody levels against Escherichia coli and Candida albicans in any of the five groups examined [46]. In a second study, we reported an elevation in mean titre of anti-Klebsiella antibodies in 24 active AS patients, whereas no such elevation was found in 28 inactive AS patients, 30 RA patients and 41 healthy control subjects [47]. This observation was later confirmed by our group with whole as well as sonicated bacteria and several other immunological techniques such as immunofluorescence and immunoblotting [48-50]. In an extensive study from Finland, antibodies were measured against salmonella lipopolysaccharide (LPS), to sodium dodecyl sulphate extracts of E. coli, Yersinia, Klebsiella and Proteus spp.; to a glycine extract antigen of a Campylobacter sp.; to Borrelia burgdorferi sonic extract antigen and to $C$. trachomatis elementary bodies. Ninety-nine AS patients and 100 healthy control subjects were studied and increased levels of IgA and IgG antibodies were observed against Klebsiella spp., although some slight elevation in IgA antibodies was also observed with $E$. coli. However, there was no significant elevation of antibody levels against antigens of Salmonella, Yersinia, Campylobacter, Borrelia and Proteus spp. and $C$. trachomatis in the AS patients investigated. AS patients were also found to have elevated levels of antibodies to LPS from Klebsiella and Shigella spp., but not to LPS from E. coli, Salmonella, Yersinia, and Campylobacter spp. [51]. Furthermore, both humoral and celllular responses against $K$. pneumoniae were elevated in 13 AS patients when compared with healthy control subjects [52]. In contrast, a quantitative reduction of $K$. pneumoniae-responsive $\mathrm{T}$ cells was found in peripheral blood lymphocytes of patients with AS compared with healthy control subjects [53]. Studies from the Netherlands have reported elevated levels of antibodies to K. pneumoniae in AS and acute anterior uveitis (AAU) patients compared with healthy control subjects [54]. Apart from antibodies to a whole cell preparation of $K$. pneumoniae which were found in Japanese AS patients, IgG antibody levels were also reported to be elevated against homologous synthetic peptides of HLA-B27 (DRED), K. pneumoniae nitrogenase reductase (DRED) [32] and pullulanase (DRDE) [35] enzymes. The presence of specific anti-K. pneumoniae antibodies in AS patients and the observation that molecular mimicry between HLA-B27 and K. pneumoniae has been defined in terms of similarity to amino acids, found in both the suspect bacteria and the genetically susceptible individuals, clearly suggest that this microbe could be the environmental trigger factor in AS. Specific anti-klebsiella antibodies in AS patients have now been reported from 16 different countries. 
If $K$. pneumoniae were present in the gut or bowel mucosa in AS, the nearest relevant lymph nodes would be in the mesentery of the gut and the pelvis. These are anatomically close to both the lumbar spine and sacroiliac joints, and, therefore, high levels of antibodies would be expected in these areas, which are the main pathological sites of disease expression in AS. If the bowel mucosa is affected, abnormalities should also be present in the local mesenteric, presacral and pelvic lymph nodes. Studies have demonstrated abnormalities in pelvic and sacral lymph nodes in AS patients by lymphangiography and it was observed that inflammation and sclerosis of the lymph node changes seemed to precede the development of radiological changes in the lumbar spine and sacroiliac joints [55]. It has been suggested that there is an increased prevalence of inflammatory bowel disease (IBD) in families of AS patients. Furthermore, ileo-colonoscopic findings in 232 patients with seronegative spondyloarthropathy demonstrated inflammatory lesions in $57 \%$ of AS patients during the active phases of the disease [56]. In a subsequent study, $25 \%$ of those patients who had chronic inflammatory changes on initial biopsy had developed Crohn's disease (CD) [57]. In a recent study, our group has shown that both AS and IBD patients have elevated levels of antibodies to $K$. pneumoniae, but not to Eubacterium, Bacteroides or Peptostreptococcus spp., E. coli or P. mirabilis [58]. These findings suggest a specific immmune response to $K$. pneumoniae in both AS and IBD. However, HLA-B27 is linked to $\mathrm{AS}$, but not to IBD.

\section{Rheumatoid arthritis}

Rheumatoid arthritis (RA) in its fully developed form is a peripheral, symmetrical, inflammatory disease that leads to destructive changes in the joints. It is associated with the presence of auto-antibodies, including rheumatoid factor, in the blood. The earliest changes in RA take place in the synovial tissues. Inflamed synovial villi adhere to the adjacent margins of articular cartilage, giving rise to a 'pannus' which is composed of fibrous tissue, infiltrated with chronic inflammatory cells. Pannus can also replace bone, leading to radiologically visible erosions which are characteristic of this disease.

The association between RA and HLA-DR haplotypes DRB1*0101, DRB1*0401, DRB1*0404, DRB1*0405 and $\mathrm{DRB}^{*} 1402$ has been well established [59]. A particular region of the DRB1 chain, from position 7074 (QRRAA), has been identified as the molecular sequence responsible for the susceptibility to develop RA [60]. The receptor theory and the molecular mimicry theory have also been proposed to explain the association of specific HLA-DR alleles with RA.

\section{Molecular mimicry, $P$. mirabilis and $R A$}

Early immunological and tissue typing studies by our group demonstrated cross-reactivity between HLA-DR4 and $P$. mirabilis [61,62]. More recently, we have identified a molecular similarity or molecular mimicry sequence ESRRAL in $P$. mirabilis haemolysin which has the same shape and charge distribution as the RA susceptibility sequence EQRRAA [63]. The ESRRAL sequence is also present in the haemolysin protein of Serratia marscescens, but not in the haemolysins produced by Streptococcus pyogenes, Str. pneumoniae, Listeria monocytogenes, Staphylococcus aureus, Clostridium perfringens, Pseudomonas aeruginosa and E. coli. Furthermore, RA patients have been found to have antibodies to both the native $P$. mirabilis haemolysin protein and to the ESRRAL peptide [64]. In related studies by independent groups, antibodies against the RA susceptibility sequence EQRRAA [65] and $P$. mirabilis ESRRAL [66] have been found in RA patients.

A characteristic feature of RA is the presence of erosions of cartilage, especially in the small joints of the hands and feet, where there is a high concentration of hyaline cartilage. Another mimicry sequence has been identified in $P$. mirabilis. The IRRET sequence of $P$. mirabilis urease shows molecular mimicry with the LRREI sequence of type XI collagen, which is a component of hyaline cartilage [64]. Furthermore, RA patients appear to have elevated levels of antibodies to P. mirabilis urease [64]. As in AS, if the molecular mimicry theory is a valid model for the pathogenesis of RA, then $P$. mirabilis organisms and antibodies to $P$. mirabilis should be detectable in RA patients during active phases of the disease.

\section{Immunological and microbiological studies}

Preliminary studies by our group reported that antibody levels against $P$. mirabilis were significantly higher in 30 RA patients than in 28 AS patients and 41 healthy control subjects [61]. Various immunological techniques have shown that RA patients with active disease have elevated levels of antibodies to P. mirabilis, but not to other bacteria $[67,68]$. This observation has been confirmed by several independent groups [6873]. Specific anti-proteus antibodies in RA patients have so far been reported from 10 different countries. Furthermore, anti- $P$. mirabilis antibody levels correlate with the ability to isolate $P$. mirabilis from mid-stream urine specimens [74]. Recently, we reported that the majority of $P$. mirabilis strains isolated from the urine of RA patients were of proticine type 3 [75]. Interestingly, proticine type 3 strains are associated with upper urinary tract infections [76]. Therefore, the hypothesis that $P$. mirabilis may play a role in the development of RA can be proposed. 


\section{Molecular mimicry and the pathology of ankylosing spondylitis and rheumatoid arthritis}

The conclusion from these extensive studies is that AS patients have specific antibodies to K. pneumoniae and RA patients have antibodies to P. mirabilis. However, only a small proportion or a subset of the antimicrobial antibodies will also have anti-self or autoimmune activity. Those bacterial antigens which carry crossreactive sequences will be immunogenic, especially around the edges of the mimicking sequences, because it is at these sites that the immune system will not recognise that it is dealing with a self antigen. Hence, there is no universal breakdown of tolerance, and the production of anti-self bacterial antibodies or autoimmune activity is part of the normal immune response when encountering partially cross-reacting antigens present in infectious micro-organisms. When such cross-reacting antibodies are present in small quantities, no complement activation will occur and there will be no cytotoxic event or inflammation. Complement activation occurs when two $\mathrm{Fc}$ segments of antibodies are aligned in close proximity to activate the $\mathrm{Clq}$ molecule of the complement system and this occurs in conditions of antigen-antibody equivalence. It is well established that the width of the equivalence zone is dependent on antigen valency [77]. In view of the large number of HLA molecules present on somatic cells (i.e., probable antigen excess), it is unlikely that antibody excess is encountered during the immune response following bacterial exposure. Antigen-antibody equivalence leading to complement activation and cellular damage is more likely. When low titres of antibody are present in the patient, the Fc segments will be too far apart to activate the complement system and therefore will not cause any inflammatory damage. The end result of inflammation is localised tissue damage and fibrosis. Therefore, theraputic interventions aimed at the removal of K. pneumoniae and P. mirabilis in AS and RA patients respectively, with consequent reduction of antibody production against these organisms, should lead to a decrease in inflammation and possibly induction of clinical remission or even arrest in the progression of these diseases. Prospective clinical studies that include close microbiological monitoring are clearly indicated to determine whether removal of these common bacteria could benefit the many patients who suffer from these debilitating diseases. There are $>250000$ AS patients and $>1$ million RA patients in the UK alone and therefore these discoveries and their possible implications for therapy merit close examination and evaluation.

\section{References}

1. Zabriskie JB, Hsu KC, Seegal BC. Heart-reactive antibody associated with rheumatic fever: characterization and diagnostic significance. Clin Exp Immunol 1970; 7: 147-159.

2. Cunningham MW, Swerlick RA. Polyspecificity of antiStreptococcal murine monoclonal antibodies and their implica- tions in autoimmunity, $J$ Exp Med 1986; 164: 998-1012.

3. Fenderson PG, Fischetti VA, Cunningham MW. Topomyosin shares immunologic epitopes with Group A Streptococcal M proteins. J Immunol 1989; 142: 2475-2481.

4. Cunningham MW, McCormack JM, Talaber LR et al. Human monoclonal antibodies reactive with antigens of the Group A Streptococcus and human heart. J Immunol 1988; 141: 2760-2766.

5. Cunningham MW, McCormack JM, Fenderson PG, Hom K, Beachey EH, Dale JB. Human and murine antibodies crossreactive with Streptococcal $\mathrm{M}$ protein and myosin recognize the sequence GLN-LYS-SER-LYS-GLN in $M$ protein. $J$ Immunol 1989; 143: 2677-2683.

6. Cunningham MW, Antone SM, Gulizia JM, McManus BM, Fischetti VA, Gauntt CJ. Cytotoxic and viral neutralising antibodies crossreact with Streptococcal M protein, enteroviruses, and human cardiac myosin. Proc Natl Acad Sci USA 1992; 89: 1320-1324.

7. Brewerton DA, Caffrey MFP, Hart FD, James DCO, Nichols A, Sturrock RD. Ankylosing spondylitis and HLA-A27. Lancet 1973; 1: 904-907.

8. Khan MA. Genetics of HLA-B27. Br J Rheumatol 1988; 27 Suppl 2: 6-11.

9. Skoskieiwicz MJ, Colvin RB, Schneeberger EE, Russell PS. Widespread and selective induction of major histocompatibility complex-determined antigens in vivo by gamma interferon. $J$ Exp Med 1985; 162: 1645-1664.

10. Bjorkman PJ, Saper MA, Samraoui B, Bennett WS, Strominger JL, Wiley DC. Structure of human class I histocompatibility antigen, HLA-A2. Nature 1987; 329: 506-512.

11. Benjamin R, Parham P. Guilt by association: HLA-B27 and ankylosing spondylitis. Immunol Today 1990; 11: 137-142.

12. Ebringer A, Cowling $\mathrm{P}$, Ngwa Suh et al. Crossreactivity between Klebsiella aerogenes species and HLA-B27 lymphocyte antigens as an aetiological factor in ankylosing spondylitis. In: Dausset J, Svejgaard A (eds) HLA and disease. Paris, INSERM. 1976: 27.

13. Theofilopoulos AN. The basis of autoimmunity: Part 1 . Mechanisms of aberrant self-recognition. Immunol Today 1995; 16: 90-98.

14. Moudgil KD, Sercarz EE. Dominant determinants in hen eggwhite lysozyme correspond to the cryptic determinants within its self-homologue mouse lysozyme: implications in shaping of the T cell repertoire and autoimmunity. J Exp Med 1993; 178: 2131-2138.

15. Lin R-H, Mamula MJ, Hardin JA, Janeway CA. Induction of autoreactive $\mathrm{B}$ cells allows priming of autoreactive $\mathrm{T}$ cells. $J$ Exp Med 1991; 173: 1433-1439.

16. Granfors K, Toivanen A. IgA-anti- Yersinia antibodies in Yersinia triggered reactive arthritis. Ann Rheum Dis 1986; 45: $561-565$.

17. Gaston JS, Life PF, Granfors K et al. Synovial T lymphocyte recognition of organisms that trigger reactive arthritis. Clin Exp Immunol 1989; 76: 348-353.

18. Hermann E, Mayet WJ, Lohse AW, Grevenstein J, Meyer Zum Büschenfelde K-H, Fleischer B. Proliferative response of synovial fluid and peripheral blood mononuclear cells to arthritogenic and non-arthritogenic microbial antigens and to the $65-\mathrm{kDa}$ mycobacterial heat-shock protein. Med Microbiol Immunol 1990; 179: 215-224.

19. Probst P, Hermann E, Meyer Zum Büschenfelde K-H, Fleischer B. Identification of the Yersinia enterocolitica urease beta subunit as a target for human synovial $\mathrm{T}$ lymphocytes in reactive arthritis. Infect Immun 1993; 61: 4507-4509.

20. Mertz AKH, Daser A, Skurnik M et al. The evolutionarily conserved ribosomal protein L23 and the cationic urease subunit of Yersinia enterocolitica $\mathrm{O}: 3$ belong to the immunodominant antigens in Yersinia triggered reactive arthritis: implications for autoimmunity. Mol Med 1994; 1: 1-5.

21. Mertz AK, Batsford SR, Curschellas E, Kist MJ, Gondolf KB. Cationic Yersinia antigen induced chronic allergic arthritis in rats. A model for reactive arthritis in humans. J Clin Invest 1991; 88: 632-642.

22. Maki-Ikola O, Leirisalo-Repo M, Kantele A, Toivanen P, Granfors K. Salmonella-specific antibodies in reactive arthritis. J Infect Dis 1991; 164: 1141-1148.

23. Granfors K, Jalkanen S, Lindberg AA et al. Salmonella lipopolysaccharide in synovial cells from patients with reactive arthritis. Lancet 1990; 335: 685-688. 
24. Inman RD, Chiu B, Johnston MEA, Vas S, Falk J. HLA class 1-related impairment in IL-2 production and lymphocyte response to microbial antigens in reactive arthritis. $J$ Immunol 1989; 142: 4256-60.

25. Granfors K, Jalkanen S, Toivanen P, Koski J, Lindberg AA. Bacterial lipopolysaccharide in synovial fluid cells in Shigella triggered reactive arthritis. J Rheumatol 1992; 19: 500.

26. Sieper J, Braun J, Wu P, Hauer R, Laitko S. The possible role of Shigella in sporadic enteric reactive arthritis. $\mathrm{Br} J$ Rheumatol 1993; 32: 582-585.

27. Welsh J, Avakian H, Cowling P et al. Ankylosing spondylitis, HLA-B27 and Klebsiella. I. Cross-reactivity studies with rabbit antisera. Br J Exp Pathol 1980; 61: 85-91.

28. Avakian H, Welsh J, Ebringer A, Entwistle CC. Ankylosing spondylitis, HLA-B27 and Klebsiella. II. Cross-reactivity studies with human tissue typing sera. Br $J$ Exp Pathol 1980; 61: 92-96.

29. Van Bohemen CG, Grumet FC, Zanen HC. Identification of HLA-B27M1 and -M2 cross-reactive antigens in Klebsiella, Shigella and Yersinia. Immunology 1984; 52: 607-610.

30. Kono DH, Ogasawara M, Effros RB, Parks MS, Waldord RL, Yu DT. Ye-1, a monoclonal antibody that cross-reacts with HLA-B27 lymphoblastoid cell lines and an arthritis causing bacteria. Clin Exp Immunol 1985; 61: 503-508.

31. Ogasawara M, Kono DH, Yu DTY. Mimicry of human histocompatibility HLA-B27 antigens by Klebsiella pneumoniae. Infect Immun 1986; 51: 901-908.

32. Schwimmbeck PL, Yu DTY, Oldstone MBA. Autoantibodies to HLA B27 in the sera of HLA B27 patients with ankylosing spondylitis and Reiter's syndrome. Molecular mimicry with Klebsiella pneumoniae as a potential mechanism of autoimmune disease. J Exp Med 1987; 166: 173-181.

33. Husby G, Tsuchiya N, Schwimmbeck PL et al. Cross-reactive epitope with Klebsiella pneumoniae nitrogenase in articular tissue of HLA-B27+ patients with ankylosing spondylitis. Arthritis Rheum 1989; 32: 437-445.

34. Ahmadi K, Wilson C, Tiwana H, Ebringer A, Shanmuganathan $\mathrm{S}$, Binder A. Antibodies to Klebsiella pneumoniae nitrogenase reductase in patients with ankylosing spondylitis. Ann Rheum Dis 1998; 57: 441.

35. Fielder M, Pirt SJ, Tarpey I et al. Molecular mimicry and ankylosing spondylitis: possible role of a novel sequence in pullulanase of Klebsiella pneumoniae. FEBS Lett 1995; 369: $243-248$.

36. Ebringer R, Cooke D, Cawdell DR, Cowling P, Ebringer A. Ankylosing spondylitis: Klebsiella and HLA-B27. Rheumatol Rehabil 1977; 16: 190-196.

37. Ebringer R, Cawdell DR, Cowling P et al. Sequential studies in ankylosing spondylitis: Association of Klebsiella pneumoniae with active disease. Ann Rheum Dis 1978; 37: 146-151.

38. Cowling P, Ebringer R, Ebringer A. Association of inflammation with raised serum IgA in ankylosing spondylitis. Ann Rheum Dis 1980; 39: 545-549.

39. Eastmond CJ, Wilshaw HE, Burgess SE, Shinebaum R, Cooke EM, Wright V. The frequency of faecal Klebsiella aerogenes in patients with ankylosing spondylitis and controls with respect to individual features of the disease. Ann Rheum Dis 1980; 39 $118-123$.

40. Hunter T, Harding GKM, Kaprove RE, Schroeder M-L. Fecal carriage of various Klebsiella and Enterobacter species in patients with active ankylosing spondylitis. Arthritis Rheum 1981; 24: 106-108.

41. Kuberski TT, Morse HG, Rate RG, Bonnel MD. Increased recovery of Klebsiella from the gastrointestinal tract of Reiter's syndrome and ankylosing spondylitis patients. $\mathrm{Br} J$ Rheumatol 1983; 22 Suppl 2: 85-90.

42. Veys EM, van Laere M. Serum $\operatorname{IgG}, \operatorname{IgM}$, and $\operatorname{IgA}$ levels in ankylosing spondylitis. Ann Rheum Dis 1977; 32: 493-496.

43. Mackiewicz A, Khan MA, Reymolds TL, van der Linden S, Kushner I. Serum IgA, acute phase proteins and glycosylation of alpha 1-acid glycoprotein in ankylosing spondylitis. Ann Rheum Dis 1989; 48: 99-103.

44. Lamm ME. Cellular aspects of immunoglobulin A. $A d v$ Immunol 1976; 22; 223-290.

45. Ebringer A. The relationship between Klebsiella infection and ankylosing spondylitis. In: Rooney PJ (ed) The gut and rheumatic disease. Baillières Clin Rheumatol International Practice and Research 1989; 3: 321-338.

46. Trull AK, Ebringer R, Panayi GS, Colthorpe D, James DCO,
Ebringer A. IgA antibodies to Klebsiella pneumoniae in ankylosing spondylitis. Scand J Rheumatol 1983; 12: 249-253. 47. Trull A, Ebringer A, Panayi GS, Ebringer R, James DCO. HLA-B27 and the immune response to enterobacterial antigens in ankylosing spondylitis. Clin Exp Immunol 1984; 55: 74-80.

48. Ebringer A, Ghuloom M, Ptaszynska T et al. Role of microorganisms in the aetiopathogenesis of HLA-B27 diseases. In: Veys E, Mielants H (eds) Spondyloarthropathies - involvement of the gut. Amsterdam, Elsevier, Excerpta Medica. 1987: 235-247.

49. Abuljadayel I, Ebringer A, Cox NL. Antibodies to Klebsiella measured by immunofluorescence. Clin Rheumatol 1989; 8: 25.

50. Shodjai-Moradi F, Ebringer A, Abuljadayel I, IgA antibody response to klebsiella in ankylosing spondylitis measured by immunoblotting. Ann Rheum Dis 1992; 51: 233-237.

51. Maki-Ikola O, Lehtinen K, Granfors K, Vainionpaa R, Toivanen P. Bacterial antibodies in ankylosing spondylitis. Clin Exp Immunol 1991; 84: 472-475.

52. Garcia-Latorre EA, Dominguez-Lopez ML, Jimenez-Zamudio LA et al. Cellular immune response to different antigenic fractions to Klebsiella pneumoniae in ankylosing spondylitis. 9th International Congress on Immunology. San Francisco 1995. Abstract vol 165.

53. Hermann E, Sucké B, Droste U, Meyer zum Büschenfelde KH. Klebsiella pneumoniae-reactive $\mathrm{T}$ cells in blood and synovial fluid of patients with ankylosing spondylitis. Arthritis Rheum 1995; 38: 1277-1282.

54. Blankenberg-Sprenkels SHD, Fielder M, Feltkamp TEW, Tiwana H, Wilson C, Ebringer A. Antibodies to Klebsiella pneumoniae in Dutch patients with ankylosing spondylitis and acute anterior uveitis and to Proteus mirabilis in rheumatoid arthritis. J Rheumatol 1998; 25: 743-747.

55. Fournier AM, Denizet D, Delagrange A. [Lymphography in ankylosing spondylarthritis.] Lymphographie dans la spondylarthrite ankylosante. J Radio Electrol Med Nucl 1969; 50: $773-784$.

56. Mielants H, Veys EM, Cuvelier C, de Vos M. Ileocolonoscopic findings in seronegative spondyloarthropathies. Br J Rheumatol 1988; 27 Suppl 2: 95-105.

57. De Vos M, Mielants H, Cuvelier C, Elewaut A, Veys E. Longterm evolution of gut inflammation in patients with spondyloarthropathy. Gastroenterology 1996; 110: 1696-1703.

58. Tiwana $\mathrm{H}$, Wilson $\mathrm{C}$, Walmsley RS et al. Antibody responses to gut bacteria in ankylosing spondylitis. Rheumatoid arthritis, Crohn's disease and ulcerative colitis. Rheumatol Int 1997; 17: $11-16$.

59. Nepom GT, Byers P, Seyfried CE et al. HLA genes associated with rheumatoid arthritis. Identification of susceptibility alleles using oligonucleotide probes. Arthritis Rheum 1989; 32:15-21.

60. Watanabe $\mathrm{Y}$, Tokunaga $\mathrm{K}$, Matsuki et al. Putative amino sequence of HLA-DRB chain contributing to rheumatoid arthritis susceptibility. J Exp Med 1989; 169: 2263-2268.

61. Ebringer A, Ptaszynska T, Corbett M et al. Antibodies to Proteus in rheumatoid arthritis. Lancet 1985; 2: 305-307.

62. Ebringer A, Cox NL, Abuljadayel I et al. Klebsiella antibodies in ankylosing spondylitis and Proteus antibodies in rheumatiod arthritis. Br J Rheumatol 1988; 27 Suppl 2: 72-85.

63. Ebringer A, Cunningham P, Ahmadi K, Wrigglesworth J, Hosseini R, Wilson C. Sequence similarity between HLA-DR1 and DR4 subtypes associated with rheumatoid arthritis and proteus/serratia membrane haemolysins. Ann Rheum Dis 1992; 51: $1245-1246$.

64. Wilson C, Ebringer A, Ahmadi K et al. Shared amino acid sequences between major histocompatibility complex class II glycoproteins, type XI collagen and Proteus mirabilis in rheumatoid arthritis. Ann Rheum Dis 1995; 54: 216-220.

65. Takeuchi F, Kosuge E, Matsuta $\mathrm{K}$ et al. Antibody to a specific HLA-DR Beta 1 sequence in Japanese patients with rheumatoid arthritis. Arthritis Rheum 1990; 33: 1867-1868.

66. Dybwad A, Forre O, Sioud M. Increased serum and synovial fluid antibodies to immunoselected peptides in patients with rheumatoid arthritis. Ann Rheum Dis 1996; 55: 437-441.

67. Tiwana H, Wilson C, Cunningham P, Binder A, Ebringer A. Antibodies to four Gram-negative bacteria in rheumatoid arthritis which share sequences with the rheumatoid arthritis susceptibility motif. Br J Rheumatol 1996; 35: 592-594.

68. Subair H, Tiwana H, Fielder M et al. Elevation in anti-Proteus antibodies in patients with rheumatoid arthritis from Bermuda and England. J Rheumatol 1995; 22: 1825-1828. 
69. Rogers P, Hassan J, Bresnihan B, Feighery C, Whelan A. Antibodies to Proteus in rheumatoid arthritis. Br J Rheumatol 1988; 27 Supp1 2: 90-94.

70. Deighton CM, Gray JW, Bint AJ, Walker DJ. Anti-Proteus antibodies in rheumatoid arthritis same sexed siblings. $\mathrm{Br} J$ Rheumatol 1992; 31: 241-245.

71. Kjeldsen-Kragh J, Rashid T, Dybwad A et al. Decrease in antiProteus mirabilis but not anti-Escherichia coli antibody levels in rheumatoid arthritis patients treated with fasting and a one year vegetarian diet. Ann Rheum Dis 1995; 54: 221-224.

72. Senior BW, McBride PDP, Morley KD, Kerr MA. The detection of raised levels of IgM to Proteus mirabilis in sera from patients with rheumatoid arthritis. J Med Microbiol 1995; 43: $176-184$.

73. Tani Y, Tiwana H, Hukuda S et al. Antibodies to Klebsiella,
Proteus and HLA-B27 peptides in Japanese patients with ankylosing spondylitis and rheumatoid arthritis. $J$ Rheumatol 1997; 24: 109-114.

74. Wilson C, Thakore A, Isenberg D, Ebringer A. Correlation between anti-Proteus antibodies and isolation rates of $P$. mirabilis in rheumatoid arthritis. Rheumatol Int 1997; 16: 187-189.

75. Wilson C, Senior BW, Tiwana H, Caparros-Wanderley W, Ebringer A. Antibiotic sensitivity and proticine typing of Proteus mirabilis strains associated with rheumatoid arthritis. Rheumatol Int 1998; 17: 203-205.

76. Senior BW. The special affinity of particular types of Proteus mirabilis for the urinary tract. $J$ Med Microbiol 1979; 12: 1-8.

77. Lachmann PJ. Complement - friend or foe? Br J Rheumatol 1987; 26: 409-415. 